\title{
Pheochromocytoma and Paraganglioma cM1 TNM Finding v8
}

National Cancer Institute

\section{Source}

National Cancer Institute. Pheochromocytoma and Paraganglioma cM1 TNM Finding v8. NCl Thesaurus. Code C141109.

Distant metastasis. (from AJCC 8th Ed.) 